\title{
Suitability of Cell-Based Label-Free Detection for Cytotoxicity Screening of Carbon Nanotubes
}

\author{
Claudia Meindl, ${ }^{1}$ Markus Absenger, ${ }^{1}$ Eva Roblegg, ${ }^{2}$ and Eleonore Fröhlich ${ }^{1}$ \\ ${ }^{1}$ Center for Medical Research, Medical University of Graz, 8010 Graz, Austria \\ ${ }^{2}$ Department of Pharmaceutical Technology, Institute of Pharmaceutical Sciences, Karl-Franzens-University of Graz, \\ 8010 Graz, Austria
}

Correspondence should be addressed to Eleonore Fröhlich; eleonore.froehlich@medunigraz.at

Received 27 May 2013; Revised 31 October 2013; Accepted 1 November 2013

Academic Editor: M. Piacentini

Copyright (C) 2013 Claudia Meindl et al. This is an open access article distributed under the Creative Commons Attribution License, which permits unrestricted use, distribution, and reproduction in any medium, provided the original work is properly cited.

\begin{abstract}
Cytotoxicity testing of nanoparticles (NPs) by conventional screening assays is often complicated by interference. Carbon nanotubes (CNTs) are particularly difficult to assess. To test the suitability of cell-based label-free techniques for this application, a panel of CNTs with different diameters and surface functionalizations was assessed by impedance-based technique ( $x$ CELLigence RTCA) and automated microscopy (Cell-IQ) compared to formazan bioreduction (MTS assay). For validation of the label-free systems different concentrations of ethanol and of amine (AMI) polystyrene NPs were used. CNTs were evaluated in various cell lines, but only endothelial EAhy926 cells and L929 and V79 fibroblasts could be evaluated in all systems. Polystyrene particles obtained similar results in all assays. All systems identified thin $(<8 \mathrm{~nm})$ CNTs as more cytotoxic than thick $(>20 \mathrm{~nm})$ CNTs, but detection by $x$ CELLigence system was less sensitive to CNT-induced cytotoxicity. Despite advantages, such as continuous monitoring and more detailed analysis of cytotoxic effects, label-free techniques cannot be generally recommended for cytotoxicity screening of NPs.
\end{abstract}

\section{Introduction}

Nanoparticles (NPs) are used in a variety of industrial, consumer, and medical products. Their application field would even be much broader if the toxicological potential was better known. For the initial evaluation of compounds cytotoxicity testing by screening assays (CSAs) is of key importance. Conventional CSAs are based on the quantification of enzyme activity, protein content, DNA content, and organelle function. These detections are based on colorimetric, fluorometric, luminescent, and, less frequently, radiometric measurements. In contrast to conventional drug compounds, however, the assessment of NPs in these assays is more problematic since they can interfere at various levels with the detection. NPs can catalyse the conversion of tetrazolium salts [1-3], absorb dyes [4, 5], and interfere with absorbance $[6,7]$ and with fluorescence $[5,8]$. They may also adsorb proteins [9], degrade indicator dyes [10], cause redox reactions [11], and interfere by light scattering $[12,13]$. Carbon nanotubes (CNTs) belong to the NPs with the highest degree of interference with CSAs $[1,2,4,14]$. Interference with assays appears to be particularly likely when the protocol affords lysis of the cells [15]. In this situation, testing by label-free techniques could be advantageous. Testing in the absence of dyes might also be important because influence of dyes on cellular function has been reported. $2^{\prime}, 7^{\prime}$-Bis(2carboxyethyl)-5-(and 6)-carboxyfluorescein (BCECF-AM), used for measurement of intracellular $\mathrm{pH}$, and rhodamine $6 \mathrm{G}$, used for labelling of mitochondria, can dose-dependently block migration in phagocytes [16].

Label-free techniques used for cell viability include refractive index-based technologies, fibre optic waveguide measurements, acoustic technologies, impedance-based instruments, and automated microscopy. Refractive indexbased technologies are particularly suitable to address receptor-mediated signalling. Fibre optic waveguide measurements are used for the detection of oxygen consumption as parameter for mitochondrial respiration and for extracellular acidification as indication for glycolysis. Acoustic technologies using resonant frequency of piezoelectric quartz crystals, impedance-based instruments, and automated microscopy are suitable for cytotoxicity testing. 
Label-free CSAs have the additional advantage that they allow continuous monitoring. Continuous measurement in contrast to endpoint detection can identify potential cellular adaptations to the toxic compound. Usually, compounds decrease viability to greater extent after longer than after shorter exposure times (e.g., [17, 18]). Adaptation to toxic stimuli, however, has also been reported. Liver cells can adaptate by changes in enzyme activities like, for instance, hexokinase, phosphoenolpyruvate carboxykinase, cyclooxygenase 2, $\gamma$-glutamyl transferase, and various biotransformation enzymes [19]. Other mechanisms include induction of membrane glycoprotein, heat shock proteins, and multidrug resistance membrane pumps. While viability of HaCAT cells exposed to the same concentration of silver NPs decreased in the order $24 \mathrm{~h}-48 \mathrm{~h}-72 \mathrm{~h}$, that of HeLa cells was also considerable lower at $48 \mathrm{~h}$ than at $24 \mathrm{~h}$. However, almost no difference was seen between viabilities at $48 \mathrm{~h}$ and $72 \mathrm{~h}$ [20]. These changes are important to know since this stress reaction might work in normal cells but not in cells that are already under stress.

Although label-free CSAs could be ideal for cytotoxicity screening of NPs, CNTs can act as semiconductors and, therefore, can interfere with the measurements based on currents. On the other hand, measurements based on optical recognition could have problems in recognizing cells in the presence of black CNT precipitates.

In the following two label-free techniques were used, the impedance-based $x$ CELLigence real time cell analyzer (RTCA) and the Cell-IQ Analyzer, based on automated microscopy. Impedance-based instruments use two gold electrodes, one sensor electrode beneath the cells and a counter electrode. An alternate current in the presence of electrolytes in the medium leads to the generation of an electric field, where the cellular plasma membrane acts as insulator. The covering of the sensor electrode with cells forces the current to pass between or under the cells and causes an increase in the impedance. Measurements by $x$ CELLigence RTCA produced reliable results in the toxicological assessment of several metal oxide $\mathrm{NPs}\left(\mathrm{ZnO}, \mathrm{CuO}[21,22] ; \mathrm{SiO}_{2}[21,22]\right)$. These NPs, however, cause only low interference with screening assays because they do not show obvious colour or tendency for precipitation. Automated microscopy works with phase contrast and takes advantage of morphological changes in the cells. The cells can be located inside an incubator or as integrated platform. With this method a distinction of specific population of cells can be made. The classification into resting (stable) cells, dead cells, and dividing cells is common [2325]. In addition, differentiated cells have been separated from nondifferentiated cells [26]. Although this technique has been employed for microscopical validation of the results, it has not been used for cytotoxicity testing.

To study the suitability of $x$ CELLigence RTCA and CellIQ analyzer for the assessment of CNTs, cytotoxicity was assessed in different cell lines in both systems, in addition to evaluation by formazan bioreduction (MTS). For validation of the label-free systems, different concentrations of ethanol and $20 \mathrm{~nm}$ amine polystyrene (AMI) particles were used. Plain and carboxyl-functionalized short CNTs in various diameters were studied.

\section{Materials and Methods}

2.1. Cells. Short CNTs $(0.5-2 \mu \mathrm{m})$ with and without $\mathrm{COOH}-$ functionalization were purchased from CheapTubes Inc. (Brattleboro, Vermont). These CNTs are synthesized by catalytic chemical vapour deposition and are purified with dilute nitric acid. Multiwalled CNTs are functionalized through repeated reductions and extractions in $\mathrm{KMnO}_{4}$ (unpublished information from the provider) and show a low amount of contaminants (ash $<1.5 \mathrm{wt} \%)$. SCNTs contain $<3 \mathrm{wt} \%$ amorphous carbon and 5-6 wt\% DWCNTs/MCNTs (http://www.cheaptubes.com/shortcoohcnts.htm\#ixzzlYPEx QhZi). SCNTs are functionalized with air oxidation (unpublished information from the provider).

Single-walled plain and carboxylated CNTs (termed as SCNT and SCNTc) with 1-2 nm diameter, purity $>90 \%$, and multi-walled CNTs in the diameters $<8 \mathrm{~nm}, 20-30 \mathrm{~nm}$ and $>50 \mathrm{~nm}$, purity $>95 \%$, termed as MCNT8 and MCNT8c, MCNT20 and MCNT20c, and MCNT50 and MCNT50c were used.

2.2. Physicochemical Characterization. $20 \mathrm{~nm}$ amine polystyrene particles (Estapor, Roche) were characterized by dynamic light scattering using a Malvern Zetasizer 3000 HS (Malvern). Particles were diluted with DMEM $+10 \%$ FBS to $200 \mu \mathrm{g} / \mathrm{mL}$ and sonicated for $20 \mathrm{~min}$. After equilibration of the sample solution to $25^{\circ} \mathrm{C}$, size and zeta potential were measured at $633 \mathrm{~nm}$ and a detection angle of $90^{\circ}$. NNLS software was used for sample analysis.

CNTs suspended in DMEM $+10 \%$ fetal bovine serum have been characterized physicochemically by Dynamic Light Scattering and Laser Doppler Velocimetry (Nanosizer, determination of size and surface charge), transmission electron microscopy (FEI Tecnai $\mathrm{G}^{2}$ 20, determination of size), and energy dispersive X-ray spectroscopy (FEI Tecnai $\mathrm{G}^{2} 20$ with Standard SUTW detector, detection of metal contamination) as described in a previous study [15]. Heavy metal contamination was shown to be below detection threshold. Diameters according to TEM were very close to the data indicated by the producer (Table 1). Lengths, however, were considerably shorter than indicated by the producer, presumably induced by the ultrasound treatment used to improve dispersion of the tubes in the medium. Surface charges of plain and carboxyl-functionalized CNTs were all slightly negative. As indicated by the producers, all CNTs have a medium conductivity of $>100 \mathrm{~S} / \mathrm{cm}$ (http://www.cheaptubes.com/shortcoohcnts.htm).

2.3. Cell Culture. DMBM-2 mouse macrophages, murine L929 and V79 Chinese hamster lung fibroblasts (Deutsche Sammlung für Mikroorganismen und Zellkulturen $\mathrm{GmbH}$ ), endothelial EAhy926 cells (kind gift from Dr. Edgell), and human MRC-5 (ATCC) fibroblasts were studied. Cells were cultured and seeded 24 hours before treatment in the medium recommended by the provider. CNTs were applied to cells suspended in cell culture medium after sonication in an Elmasonic S40 water bath (ultrasonic frequency: $37 \mathrm{kHz}$, 
TABLE 1: Characterization of CNTs suspended in DMEM + 10\% FBS by Dynamic Light Scattering and Laser Doppler Velocimetry (DLS/LDV) and transmission electron microscopy (TEM).

\begin{tabular}{|c|c|c|c|c|c|c|}
\hline \multirow{2}{*}{$\begin{array}{l}\text { Sample } \\
\text { CNT }\end{array}$} & \multicolumn{2}{|c|}{ DLS/LDV data } & \multicolumn{4}{|c|}{ TEM data } \\
\hline & $\begin{array}{l}\text { Hydrodynamic } \\
\text { size }(\mathrm{nm})\end{array}$ & $\zeta(\mathrm{mV})$ & $\begin{array}{c}\text { Diameter of single } \\
\text { CNTs (nm) }\end{array}$ & $\begin{array}{l}\text { Length of single } \\
\text { CNTs (nm) }\end{array}$ & $\begin{array}{c}\text { Diameter of CNT } \\
\text { bundles }(\mathrm{nm})\end{array}$ & $\begin{array}{c}\text { Length of CNT } \\
\text { bundles (nm) }\end{array}$ \\
\hline SCNT & 16.4 & -9.72 & $\sim 2 \mathrm{~nm}$ & n.a. & $28.3 \pm 10.6$ & $543 \pm 60.8$ \\
\hline SCNTc & 15.7 & -8.1 & $\sim 2 \mathrm{~nm}$ & n.a. & $62.5 \pm 41.9$ & $816 \pm 275.4$ \\
\hline MCNT8 & 26.8 & -6.96 & $4.7 \pm 0.48$ & $222 \pm 126.2$ & n.a. & n.a. \\
\hline MCNT8c & 16.3 & -9.64 & $4.2 \pm 0.8$ & $217 \pm 117.9$ & $24.3 \pm 5.1$ & $600 \pm 282.8^{*}$ \\
\hline MCNT20 & 124.4 & -9.78 & $18.9 \pm 0.9$ & $446 \pm 77.9$ & n.a. & n.a. \\
\hline MCNT20c & 38.8 & -10.3 & $15.3 \pm 2.5$ & $251 \pm 94.4$ & n.a. & n.a. \\
\hline MCNT50 & 51.9 & -7.28 & $62.8 \pm 5.7$ & $355 \pm 96.4$ & n.a. & n.a. \\
\hline MCNT50c & 50.4 & -11.0 & $63.6 \pm 11.3$ & $392 \pm 195.3$ & n.a. & n.a. \\
\hline
\end{tabular}

n.a.: not analysed.

${ }^{*}$ Fraction in bundles approx. $50 \%$.

$40 \mathrm{~W}$, Elma) for $20 \mathrm{~min}$. Exposures were performed at $37^{\circ} \mathrm{C}$ in a $95 \%$ air $/ 5 \% \mathrm{CO}_{2}$ atmosphere.

2.4. Cytotoxicity by Formazan Bioreduction. Cells were seeded EAhy 926 cells: $1 * 10^{4}$ /well; L929, MRC-5, and V79: $1.25 * 10^{4} /$ well; DMBM- $2: 3 * 10^{4} /$ well $)$ and evaluated after $4 \mathrm{~h}$, $24 \mathrm{~h}$, and $48 \mathrm{~h}$ of exposure to particles and EtOH. CellTiter 96 AQueous Nonradioactive Cell Proliferation Assay (Promega) was used according to the manufacturer's instructions. Not ingested CNTs were removed by repeated washings with PBS. $20 \mu \mathrm{L}$ of the combined MTS/PMS solution was added to $100 \mu \mathrm{L}$ fresh medium in each well and plates were incubated for 2 hours at $37^{\circ} \mathrm{C}$ in the cell incubator. The supernatant was transferred to a new plate to ensure that the signal was not influenced by absorbance of CNTs incorporated into cells. For the testing of ethanol and $20 \mathrm{~nm}$ AMI particles, washing and transfer of the supernatant to a new plate were omitted and absorbance was read at $490 \mathrm{~nm}$ on a plate reader (SPECTRA MAX plus 384, Molecular Devices).

2.5. Cytotoxicity by Impedance Measurement. Experiments were carried out using the $x$ CELLigence RTCA DP instrument (Roche Diagnostics $\mathrm{GmbH}$ ) which was placed in a humidified incubator at $37^{\circ} \mathrm{C}$ and $5 \% \mathrm{CO}_{2}$. Experiments were performed using modified 16-well plates (E-plates, Roche Diagnostics $\mathrm{GmbH}$ ). Microelectrodes were attached at the bottom of the wells for impedance-based detection and $100 \mu \mathrm{L}$ of cell-free growth medium was added to the wells. After leaving the devices at RT for $30 \mathrm{~min}$, the background impedance for each well was measured. $50 \mu \mathrm{L}$ of the cell suspension containing $1 * 10^{4}$ EAhy 926 cells, $2 * 10^{4}$ DMBM2, $1.25 * 10^{4} \mathrm{~L} 929$, and MRC-5 cells, and $1 * 10^{4}$ V79 cells was seeded into the wells. Cell numbers that allowed optimum growth over the entire incubation period were determined for every cell line in pilot experiments. After leaving the plates at room temperature for $30 \mathrm{~min}$ to allow cell attachment, plated were transferred into the RTCA DP device and impedance monitored by the $x$ CELLigence system. After $24 \mathrm{~h}$ (when the cell index had reached at least 1.0), $50 \mu \mathrm{L}$ of nanoparticles suspended in medium or EtOH in medium was added. Each concentration was tested in duplicate within the same experiment. Cell index (CI) was monitored every $15 \mathrm{~min}$ for $48 \mathrm{~h}$ and data recorded by the supplied RTCA software (Figure 1(a)). For comparison with MTS data, raw data with high time resolution resulting from independent $x$ CELLigence experiments were reduced to a lower time resolution by selecting only the data points corresponding with the time points of the MTS assay. Data were imported in Excel and CI-data normalized to untreated cultures.

2.6. Cell Proliferation and Morphology Studies. Cells were seeded onto 24 -well plates (EAhy 926 cells: $1 * 10^{5} /$ well; fibroblasts L929, MRC-5, and V79:5*10 $/$ /well; DMBM- $2: 2 *$ $10^{5} /$ well) prior to the exposur. After addition of nanoparticles or $\mathrm{EtOH}$ in medium, cells were monitored with integrated optics for phase contrast imaging and machine vision technology in a humidified, $5 \% \mathrm{CO}_{2}$ atmosphere at $37^{\circ} \mathrm{C}$ for $48 \mathrm{~h}$ (Cell-IQ, Chip-man Technologies Ltd). Images were captured automatically from 4 positions per well at $1 \mathrm{~h}$ intervals. A protocol for examining cell numbers and morphology with Cell-IQ analyzer software was created according to manufacturer instructions. Briefly, segmentation parameters were first adjusted to recognize cells and classify them into necrotic, dividing, apoptotic, and stable (G1-phase) cells. In addition, a class was added for CNTs and cell debris + background (garbage). The protocol was tested and optimized by comparing software classification of a set of sample images with manual classification. The protocol was then used to analyse images taken during Cell-IQ experiments (Figure 1(b)). Data were exported to Microsoft Excel and analysed further. For comparison with MTS data, raw data with high time resolution resulting from independent Cell-IQ experiments were reduced to a lower time resolution by selecting only the data points corresponding with the time points of the MTS assay. First, garbage and CNTs were subtracted from total cell numbers (corrected total cell numbers). The numbers of resting, necrotic, and dividing cells were then normalized to 100 corrected total cells. This was necessary because each observation field contained different numbers of cells at 


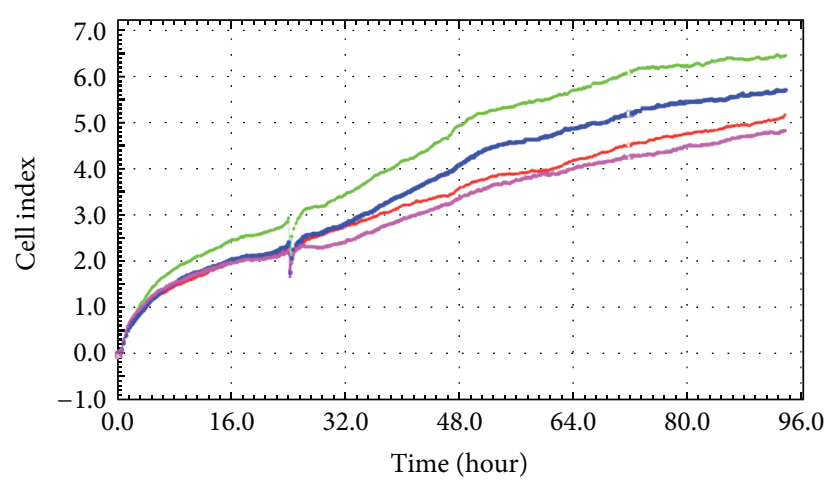

(a)

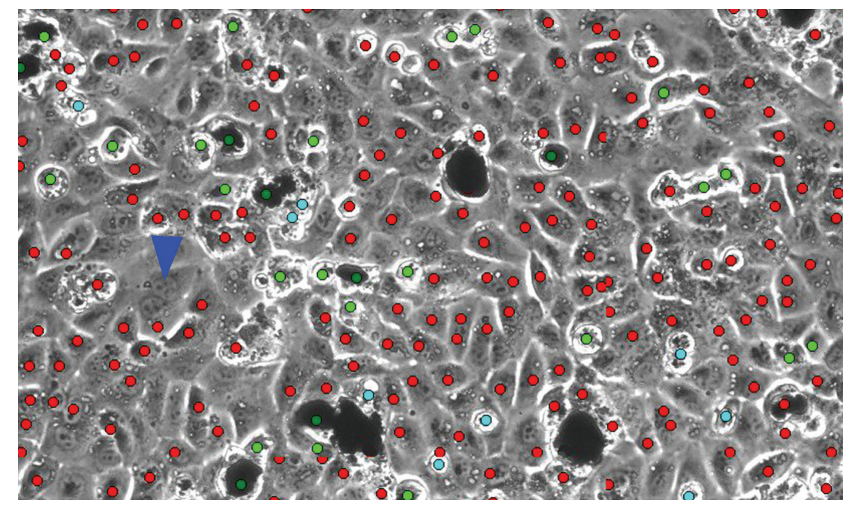

(b)

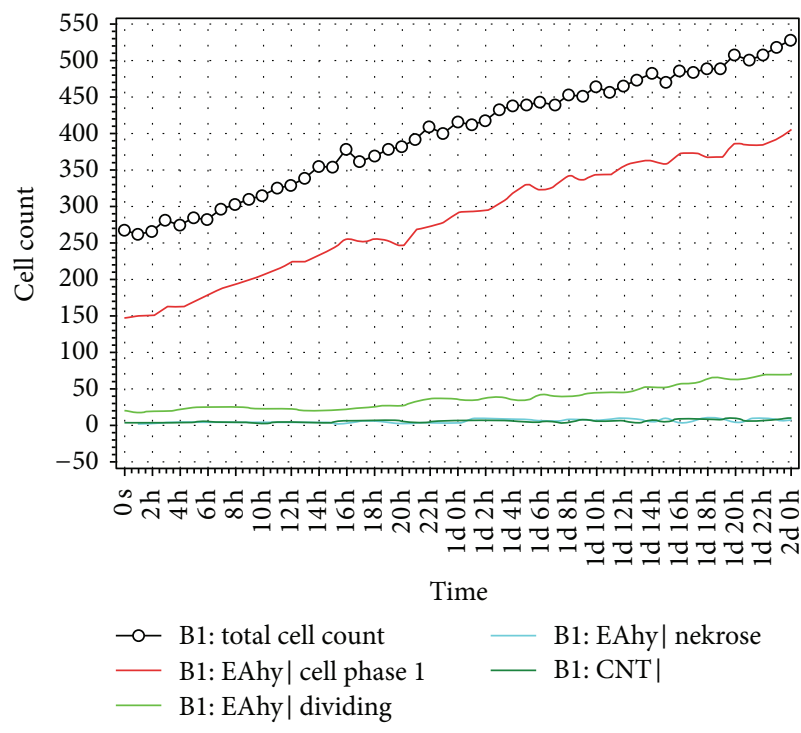

(c)

Figure 1: Raw data of $x$ CELLigence and Cell-IQ analysis software. (a) Growth curve of EAhy cells, untreated (green and red) and in the presence of $25 \mu \mathrm{g} / \mathrm{mL}$ MCNT20 (blue and pink). Image analysis by Cell-IQ software. (b) Classification of cells into stable (G1 cells, red), dividing cells (light green), necrotic cells (turquoise), and CNTs (dark green). Binucleated cells have to be identified manually (arrow head). (c) Time-related changes in the number of stable cells (red), dividing cells (light green), necrotic cells (turquoise), and CNTs (dark green) based on this classification are displayed in a graph.

the start. The normalized number in the respective class was then related to the number in the untreated cultures as $100 \%$.

2.7. Statistical Analysis. Data from three to four independent experiments were subjected to statistical analysis. This data is represented as means \pm S.D. data and has been analyzed with one-way analysis of variance (ANOVA), followed by a Tukey-HSD post hoc test for multiple comparisons (SPSS 19 software). Results with $P$ values $<0.05$ were considered to be statistically significant.

\section{Results}

3.1. Physicochemical Characterization of CNTs. $20 \mathrm{~nm}$ AMI particles were $54 \mathrm{~nm}$ large with a zeta potential $(\zeta)$ of $-9.02 \mathrm{mV}$ in the exposure medium, as characterized by Dynamic Light Scattering and Laser Doppler Velocimetry. CNTs, in addition to Dynamic Light Scattering, were also characterized by transmission electron microscopy and EDX analysis, as described earlier [15]. Diameters as determined by TEM were similar to what was indicated by the producer. Hydrodynamic diameters, with the exception of MCNT50, were 2-3 times larger than indicated. All CNTs possessed a slightly negative surface charge. Heavy metal contamination was below threshold. A summary of CNT parameters is presented in Table 1.

3.2. Suitability of Cell Lines for Label-Free Detection. Regulatory cytotoxicity testing of adherent cells is performed at the end of the logarithmic phase, at $80 \%$ confluency (EN/ISO 10993-5 guideline). Since the growth area of E-plates wells $\left(0.2 \mathrm{~cm}^{2}\right)$ is smaller than that of 96 -well plates $\left(0.32 \mathrm{~cm}^{2}\right)$ and only one tenth of 24 -well plate $\left(2 \mathrm{~cm}^{2}\right)$, different cell numbers had to be seeded. Seeding densities from the MTS assay were tested and potentially adapted in pilot experiments 


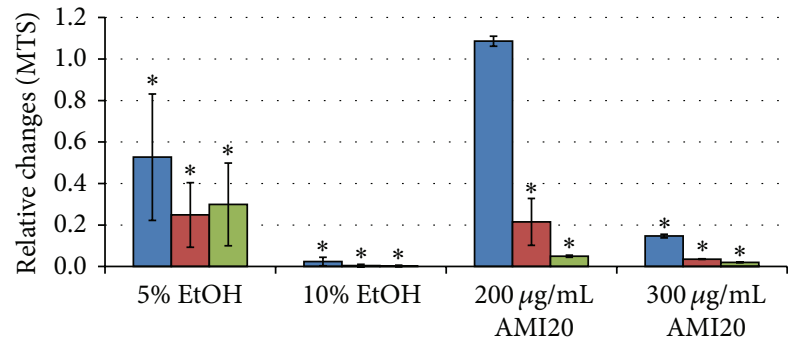

(a)

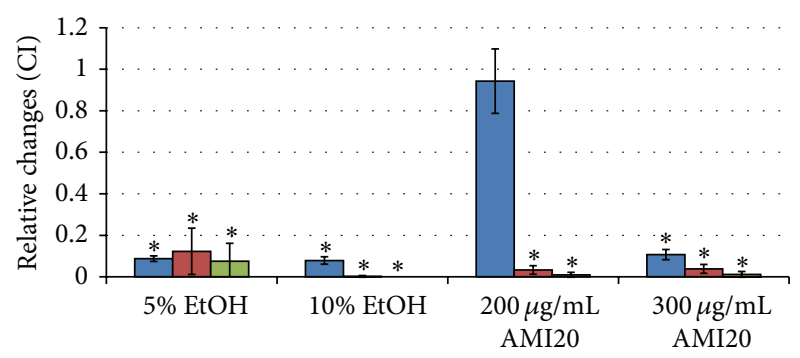

(b)

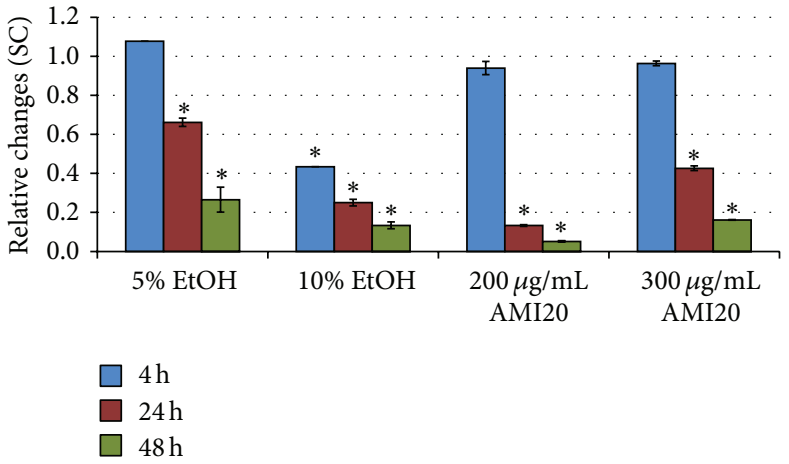

(c)

FIGURE 2: EAhy926 cells treated for $4 \mathrm{~h}, 24 \mathrm{~h}$, and $48 \mathrm{~h}$ with different concentrations of ethanol (EtOH) and 20 nm amine polystyrene particles (AMI20) assessed by formazan bioreduction (MTS), according to cell index changes in the $x$ CELLigence system (CI), and as stable cells (SC) according to image analysis by Cell-IQ software $(n=3)$. Changes are normalized to untreated controls as 1 and significant changes are $(P<0.05)$ indicated by asterisk.

on the label-free systems in order to allow $48 \mathrm{~h}$ of recording in untreated cultures (Table 2).

While EAhy926 and L929 cells could be studied in all systems, DMBM-2 cells could not be assessed neither in $x$ CELLigence system nor in Cell-IQ. MRC-5 could be analysed in the $x$ CELLigence system but not in the CellIQ-system, while V79 were suitable for Cell-IQ but not for $x$ CELLigence system.

The $x$ CELLigence system worked best with endothelial cells. While DMBM-2 cells and V79 cells, independent from the seeding density, did not reach the required cell index of 1 , EAhy 926 cells reached a cell index of $2.5 \pm 0.5$. The fibroblasts reached lower values of $1.7 \pm 0.5$ (MRC-5) and $1.3 \pm 0.8$ (L929). After $48 \mathrm{~h}$ the cell index of the EAhy926 cells had further increased to $3.9 \pm 0.7$, while it remained constant for the fibroblasts.

For the evaluation in the Cell-IQ, epithelioid shape was better than spindle shape. MRC-5 cells were too large to fit into the image window of the classification library, which made reliable cell classification impossible. Classification of V79 cells worked less reliably due to variation in the (patchy) growth pattern.

3.3. Assessment of Control Substances. To verify whether all systems identified toxicity of conventional substances or of particles that did not show obvious interference with assay systems, cells were exposed to different concentrations of EtOH and $20 \mathrm{~nm}$ AMI particles. While no significant
TAble 2: Seeding densities for MTS, xCELLigence, and Cell-IQ system $\left(\right.$ cells $\left./ \mathrm{cm}^{2}\right)$.

\begin{tabular}{lccc}
\hline & MTS & $x$ CELLigence & Cell-IQ \\
\hline EAhy926 & 30000 & 50000 & 50000 \\
DMBM-2 & 93750 & 100000 & 100000 \\
L929 & 37500 & 62500 & 25000 \\
MRC-5 & 37500 & 62500 & 25000 \\
V-79 & 33000 & 50000 & 25000 \\
\hline
\end{tabular}

reduction in viability was seen in the MTS, $x$ CELLigence system, and Cell-IQ Analyzer after exposure to 2.5\% ethanol, $5 \%$ and $10 \%$ EtOH reduced viability dramatically (Figure 2).

Upon exposure to $20 \mathrm{~nm}$ AMI, all systems showed concordant findings with no decrease in concentration of $100 \mu \mathrm{g} / \mathrm{mL}$ but strong decreases after exposure to $200 \mu \mathrm{g} / \mathrm{mL}$ and $300 \mu \mathrm{g} / \mathrm{mL}$ (Figure 2). Decreases of stable cells in Cell-IQ after exposure to $200 \mu \mathrm{g} / \mathrm{mL} 20 \mathrm{~nm}$ AMI particles were more pronounced than those after $300 \mu \mathrm{g} / \mathrm{mL}$. Inspection of the cultures treated with $300 \mu \mathrm{g} / \mathrm{mL}$ AMI particles showed that they contained much cell debris, which apparently interfered with the classification process.

When changes in Cell-IQ were displayed as dividing and necrotic cells, it is obvious that the pattern compared to untreated cells was already altered after exposure to $2.5 \%$ EtOH at all time points (Figure 3(a)). The fraction of dividing cells was decreased and that of necrotic cells increased. 


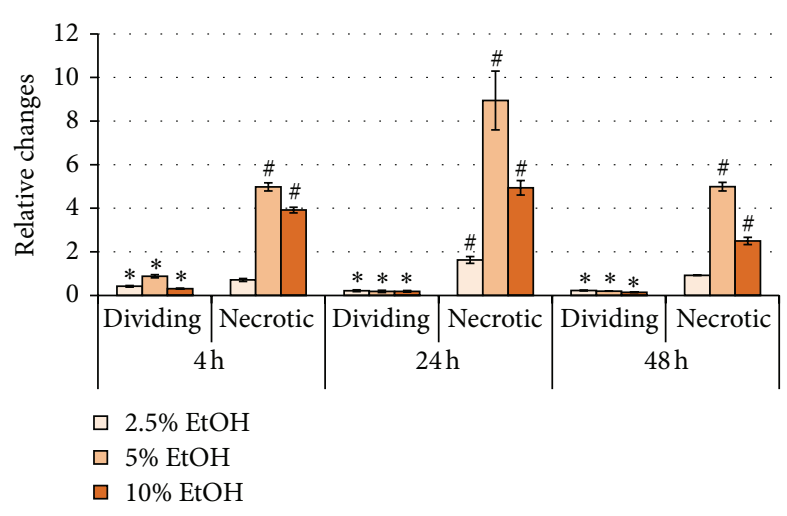

(a)

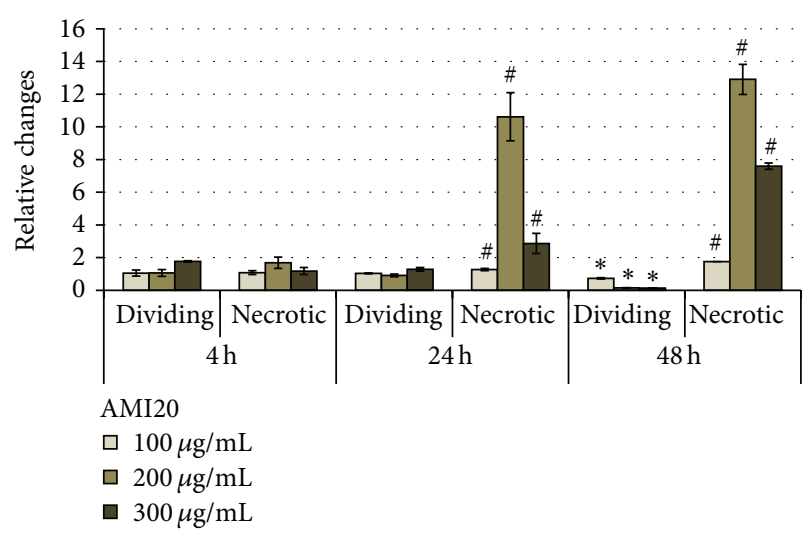

(b)

FIGURE 3: Cell-IQ software quantification of dividing and necrotic EAhy926 cells exposed to different concentrations of ethanol (EtOH (a)) and $20 \mathrm{~nm}$ amine polystyrene particles (AMI20 (b)). Changes are normalized to untreated controls as 1 . Significant $(P<0.05)$ decreases are marked by asterisk and significant increases are indicated by hatch.

At concentrations of AMI particles, which did not reduce the fraction of stable cells $(100 \mu \mathrm{g} / \mathrm{mL})$, changes in the fraction of dividing and necrotic cells compared to untreated controls were obvious already after $24 \mathrm{~h}$ and $48 \mathrm{~h}$ of exposure.

With CNTs, differences between the effects of 25,50 , and $100 \mu \mathrm{g} / \mathrm{mL}$ were relatively small. Therefore, in the following, the effects of $100 \mu \mathrm{g} / \mathrm{mL}$ are described in more detail, while effects of lower concentrations will only be summarized in the final overview.

3.4. Cytotoxicity of CNTs in the MTS Assay. Decreases in viability were more pronounced for SCNTc, MCNT8, and MCNT8c in all cell types. After $4 \mathrm{~h}$ at a concentration of $100 \mu \mathrm{g} / \mathrm{mL}$ the following changes were observed (Figure 4): all CNTs produced significant decreases in viability of EAhy926 cells and only CNTs with diameters $<8 \mathrm{~nm}$ induced significant decreases in L929 cells. SCNTc, MCNT8, and MCNT8c induced significant decreases in V79 cells and SCNTc, MCNT8, and MCNT50 in MRC-5 cells. After $24 \mathrm{~h}$, incubation with SCNT and MCNT20c also decreased viability in V79 cells and MCNT8c, MCNT20, and MCNT50c in MRC- 5 cells. After $48 \mathrm{~h}$, with the exception of MCNT20, MCNT50, MCNT50c in L929 and MCNT20 in V79 cells, all CNTs caused significant decreases in viability.

3.5. Cytotoxicity by $x$ CELLigence RTCA. After $4 \mathrm{~h}$, the relative cell index of EAhy926 cells was strongly decreased $(<80 \%)$ after incubation with SCNT and SCNTc. After $24 \mathrm{~h}$ also incubation with MCNT8, MCNT8c, and MCNT50 showed pronounced viability loss (Figure 5). After $24 \mathrm{~h}$, viability of L929 cells was significantly reduced after incubation with MCNT20c. Transient decrease of viability was seen for MCNT20. The cytotoxicity pattern of MRC-5 cells was very similar to that of EAhy926 cells with prominent decreases for SCNT, SCNTc, and MCNT8 and lower cytotoxicity of the remaining CNTs. Differences between $24 \mathrm{~h}$ and $48 \mathrm{~h}$ of exposure were minimal.
3.6. Cytotoxicity by Cell-IQ Analyzer. Stable cells after incubation of EAhy 926 cells with all CNTs for $4 \mathrm{~h}$ at a concentration of $100 \mu \mathrm{g} / \mathrm{mL}$ were significantly decreased (Figure 6). In L929 cells, SCNTc and MCNT8c caused significant decreases after $4 \mathrm{~h}$, while decreases for SCNT, MCNT8, and MCNT20c were significant only after $24 \mathrm{~h}$. A transient decrease in viability after $24 \mathrm{~h}$ was observed after incubation with MCNT50. Viability of V79 was decreased for incubations with all CNTs, except MCNT20, after $4 \mathrm{~h}$.

Based on earlier findings [15], disruption of membrane integrity leading to necrosis was identified as major cytotoxic mechanism of CNTs and, therefore, the contribution of necrotic cells was analysed in EAhy926, L929, and V79 cells. While no necrotic cells could be identified in V79 cultures, strong increases in necrotic EAhy926 cells were identified after CNT exposure (Figure 7(a)). L929 cells reacted with lower increases in necrotic cells to stimulation with CNTs. While all CNTs increased the rate of necrotic cells, most dramatic increases were seen for MCNT8, MCNT8c in EAhy 926 cells (maximum 35-fold) and for SCNTc (maximum 14.9-fold) in L929 cells. Based on an arbitrary threshold set at a 10-fold increase of necrotic cells, CNTs $<8 \mathrm{~nm}$ induced slightly more often (in 5/24 exposures of EAhy 926 cells and $3 / 24$ exposures of L929 cells) necrosis than thick $>20 \mathrm{~nm}$ CNTs (2/24 exposures of EAhy926 cells and 1/24 exposures of L929 cells). The strongest induction of necrosis was seen in EAhy926 cells and in L929 for thin CNTs after $4 \mathrm{~h}$. Thick CNT induced necrosis in EAhy926 cells after $4 \mathrm{~h}$ and in L929 after longer incubation times. Carboxylation did not have an obvious influence on induction of necrosis.

Dividing cells were identified as potential reaction to CNT exposure. Increases in the fraction of proliferating cells were observed in EAhy926 cells, but rarely in L929 cells (Figure 7(b)). Increases in EAhy926 cells occurred after $4 \mathrm{~h}$ of exposure. Proliferation of V79 cells was markedly increased upon stimulation with all CNTs, except SCNT. This increase was usually obvious only after $48 \mathrm{~h}$. In V79 cells, CNTs $<8 \mathrm{~nm}$ induced proliferation to a lower extent than CNTs $>20 \mathrm{~nm}$ 


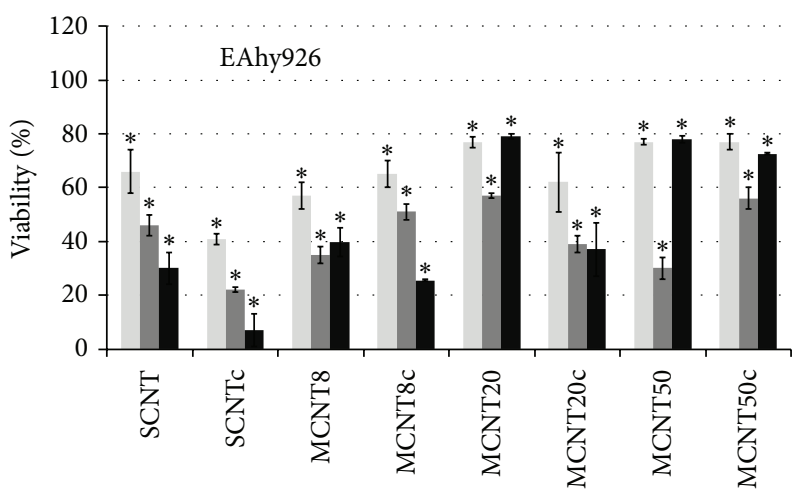

(a)

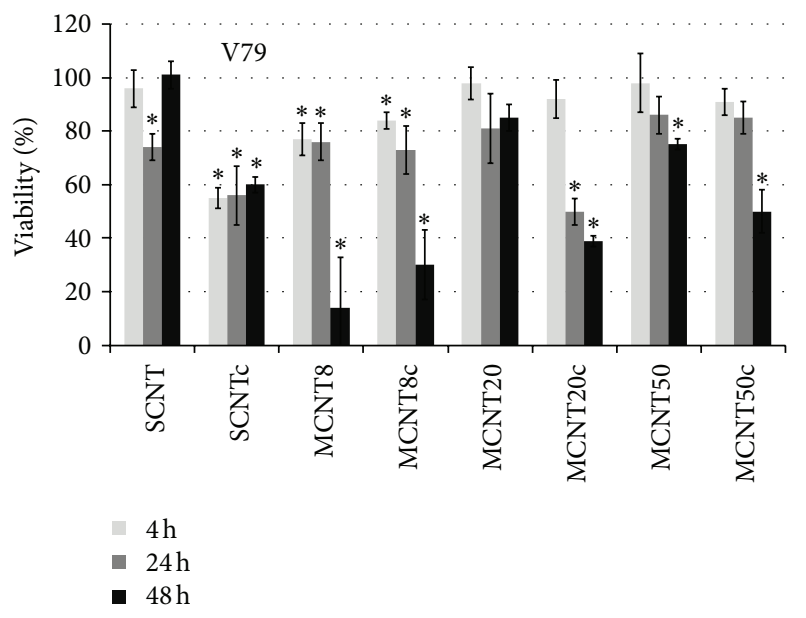

(c)

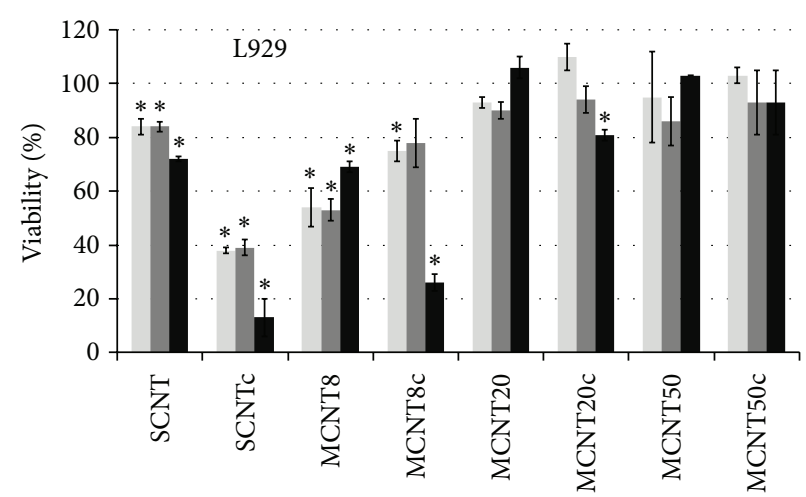

(b)

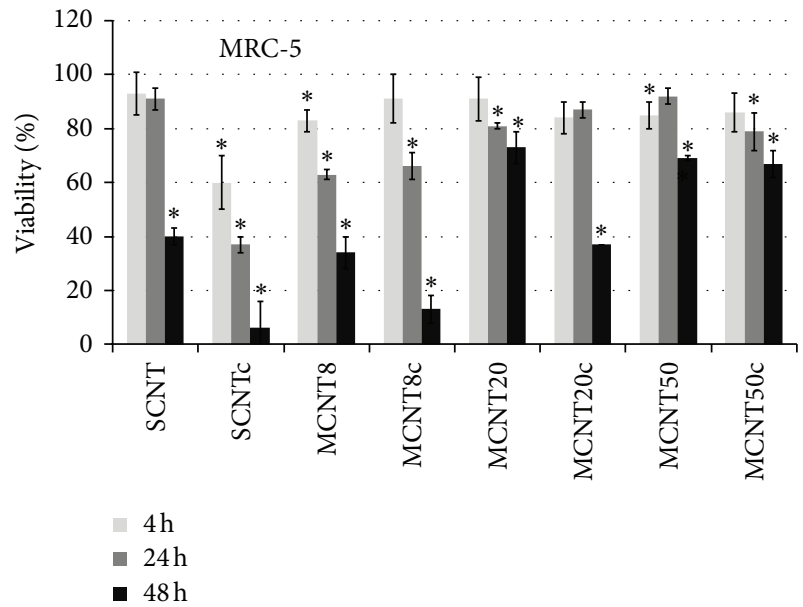

(d)

FIGURE 4: Viability according to formazan bioreduction (MTS assay) in different cell lines after exposure to CNTs $(n=4)$. Untreated cells are set as $100 \%$. Significant changes are marked by asterisk.

6/24 versus 11/24 exposures. Carboxylation did not appear to have an obvious influence on induction of proliferation.

3.7. Comparison of Cytotoxic Reaction in the Different Techniques. Decreases of viability to $<80 \%$ were used for comparison of the three techniques because, independent of the technique, such decreases were significant. In general, $x$ CELLigence RTCA data produced a lower number of CNT exposures with decreases $<80 \%$ (Figure $8(\mathrm{a})$ ). By contrast, this system was more sensitive for detection of EtOH cytotoxicity (Figure 2). Cell-IQ and MTS analysis were similarly sensitive for cytotoxicity of CNTs in EAhy926 and L929 cells, while more CNTs were classified as cytotoxic by Cell-IQ than by MTS in V79 cells. Lower decreases in stable cells were recorded in Cell-IQ measurements after exposure to EtOH than in both other screening systems. When changes in dividing and necrotic cells were included in the evaluation, automated microscopy identified cytotoxicity at lower concentrations of EtOH and AMI particles than the other techniques.

Cell lines showed different sensitivities to the cytotoxic effects of CNTs. According to MTS, all CNTs induced decreases to $<80 \%$ viability after $4 \mathrm{~h}$ in EAhy 926 cells, while only SCNTc, MCNT8, and MCNT8c produced this decrease in L929 cells. SCNTc and MCNT8 decreased viability to $<80 \%$ in V79 cells and SCNTc in MRC-5 cells. The $x$ CELLigence RTCA identified SCNT, SCNTc, and MCNT50 as cytotoxic according to the definition mentioned above in EAhy 926 cells and SCNT and MCNT8 in L929 cells. In Cell-IQ analysis all CNTs, except SCNT and MCNT50, were identified as cytotoxic in EAhy926 cells, SCNTc and MCNT8c in L929 cells, and all CNTs, except MCNT20, in V79 cells.

Decrease of cell viability to $<80 \%$ after $4 \mathrm{~h}$ was induced by thin $(<8 \mathrm{~nm})$ CNTs more often than thick $(>20 \mathrm{~nm})$ CNTs. Out of the 24 exposure conditions of EAhy926 cells with different concentrations of CNTs, according to MTS assay, 7 (thin CNTs) versus 5 (thick CNTs) exposures reduced viability after $4 \mathrm{~h}$. The corresponding ratios in $x$ CELLigence RTCA were $2 / 24$ for thin and $1 / 24$ for thick CNTs and in Cell-IQ analysis $9 / 24$ for thin and 5/24 for thick CNTs. In L929 cells 4/24 exposures to thin CNTs and 0/24 exposures to thick CNTs decreased viability according to MTS and CellIQ analyses. The corresponding ratios in $x$ CELLigence RTCA were $3 / 24$ for thin CNTs and 0/24 for thick CNTs. In the MTS assay 2/24 exposures to thin CNTs versus 0/24 exposures to thick CNTs decreased viability in V79 cells. Viability decreases according to Cell-IQ analysis (10/24 for thin CNTs 


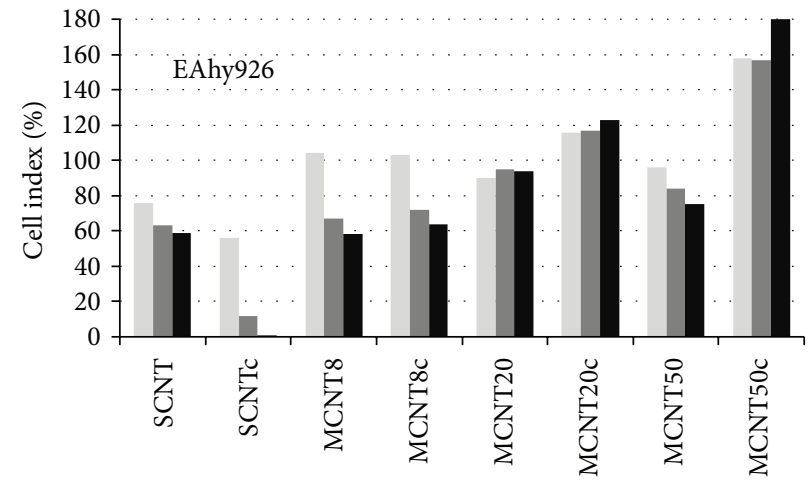

(a)

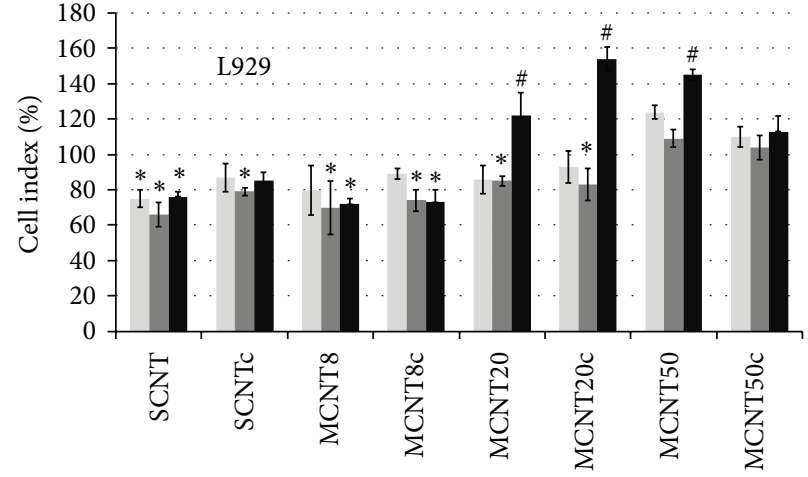

(b)

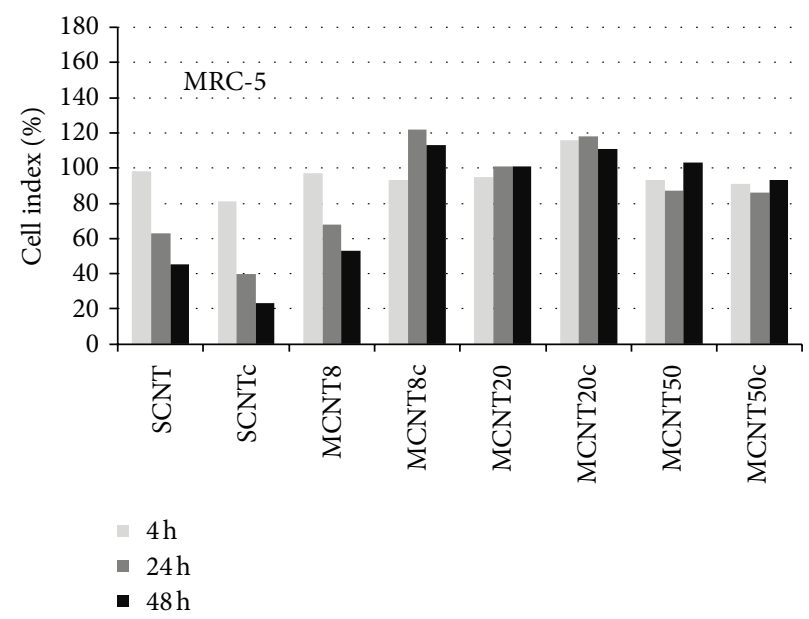

(c)

FIGURE 5: Changes in cell index assessed by $x$ CELLigence system in different cell lines after exposure to CNTs normalized to untreated cells as $100 \%$ (L929, $n=3$; other cell lines $n=2$ ). Significant changes are marked by asterisk and increases by hatch.

and 9/24 for thick CNTs) were roughly similar. Only SCNTc reduced viability in MRC-5 cells according to the MTS assay and no CNTs decreased viability in $x$ CELLigence RTCA.

Adaptation to the action or recovery from cytotoxicity was studied by comparing viability rates at $4 \mathrm{~h}, 24 \mathrm{~h}$, and $48 \mathrm{~h}$ of exposure and look at time-dependent increases. The continuous monitoring by $x$ CELLigence RTCA and Cell-IQ Analyzer allows the evaluation of additional time points. This, however, appeared not to be necessary because the shape of the growth curves did not reveal changes that were not identified also by comparison of viability at $4 \mathrm{~h}, 24 \mathrm{~h}$, and $48 \mathrm{~h}$. Increases in viability were usually observed at $48 \mathrm{~h}$ and predominantly in L929 cells (Figure 7(b)). xCELLigence RTCA identified a greater number of cellular recoveries than MTS and Cell-IQ Analyzer.

\section{Discussion}

This study shows that cytotoxicity of CNTs can be assessed by formazan bioreduction (MTS assay), impedance measurements ( $x$ CELLigence RTCA), and automatic microscopy (Cell-IQ Analyzer) with different sensitivity. All assays qualified thin $(<8 \mathrm{~nm})$ CNTs as more cytotoxic than thick
(>20 nm) CNTs. This classification was most obvious in L929 cells and less distinct in the other cell lines and clearer in the MTS assay and Cell-IQ Analyzer than with $x$ CELLigence. The degree of cytotoxic damage was higher in EAhy926 cells than in the other cell lines. Analysis by Cell-IQ Analyzer revealed a higher degree of induction of necrosis by thin CNTs and an increased proliferation rate upon incubation with thick CNTs. Time-dependent recovery to the cytotoxic action of CNTs was more pronounced for thick than for thin CNTs. A cell-specific reaction pattern to CNTs could be discerned: EAhy926 cells showed relatively high rates of necrosis, moderate proliferation rates, and little recovery from cytotoxicity. L929 cells, by contrast, showed moderate increases in the rate of necrotic and dividing cells but better recovery from CNT cytotoxicity than the other cell lines. In V79 cells, no necrotic cells were identified, proliferation was high, and some recovery to damage by CNTs was observed.

When selecting a screening method for the evaluation of NPs, label-free techniques may appear a good choice since interference with assay compounds can be prevented. The suitability of the label-free methods used in this study will be discussed regarding two aspects: problems inherent to the technology and specific problems with CNTs and not encountered with ethanol and polystyrene particles. 


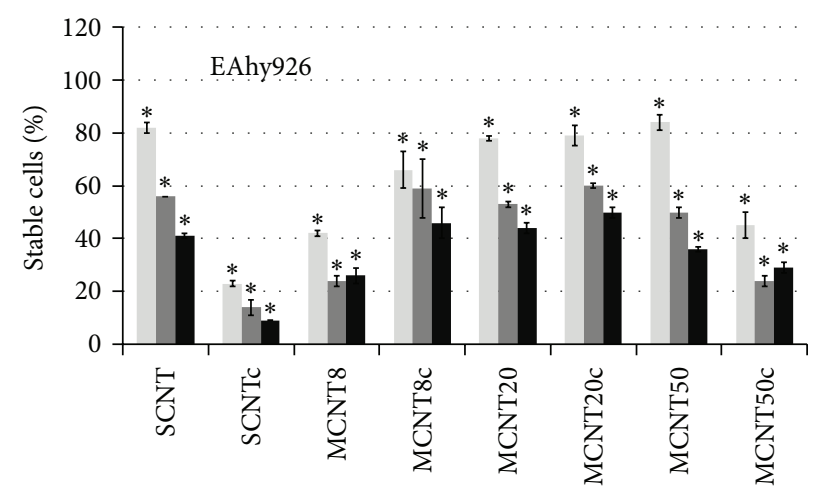

(a)

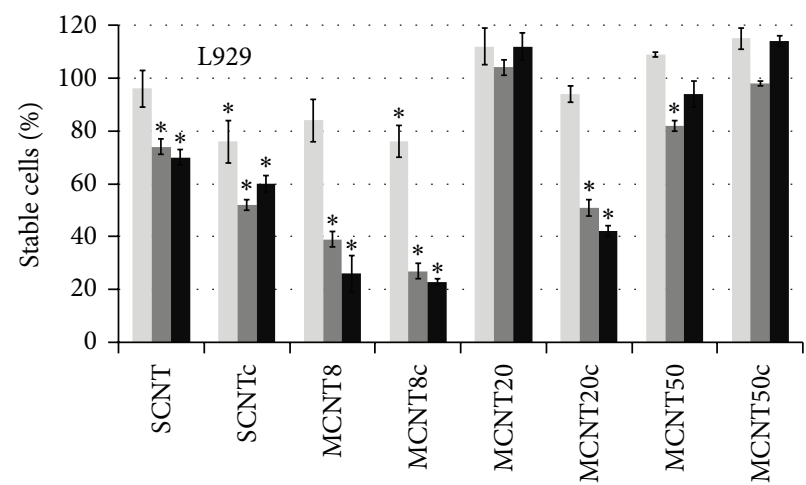

(b)

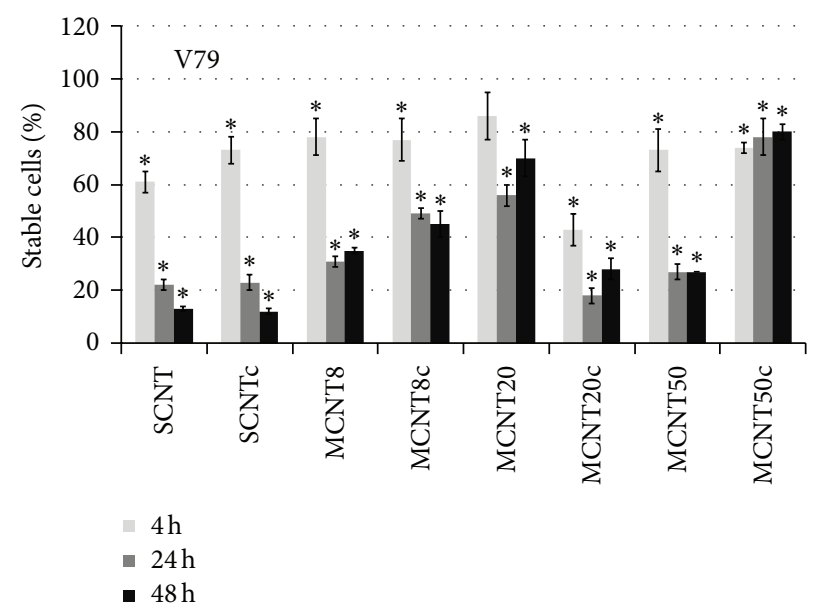

(c)

Figure 6: Fraction of stable cells according to Cell-IQ analysis in different cell lines exposed to CNTs $(n=4)$. Untreated cells are set as $100 \%$. Significant changes are marked by asterisk.

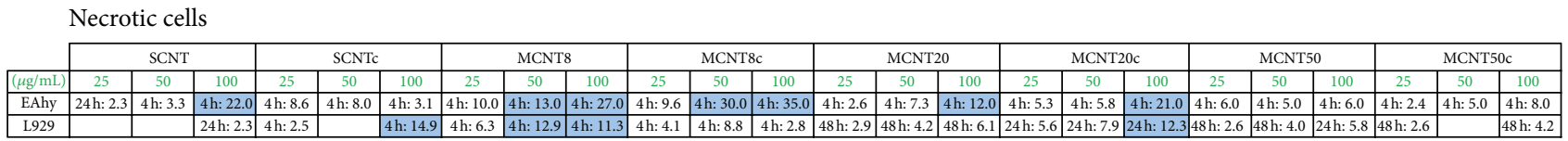

Necrotic cells $>10.0$-fold

(a)

\begin{tabular}{|c|c|c|c|c|c|c|c|c|c|c|c|c|c|c|c|c|c|c|c|c|c|c|c|c|}
\hline & \multicolumn{3}{|c|}{ SCNT } & \multicolumn{3}{|c|}{ SCNTC } & \multicolumn{3}{|c|}{ MCNT8 } & \multicolumn{3}{|c|}{ MCNT8c } & \multicolumn{3}{|c|}{ MCNT20 } & \multicolumn{3}{|c|}{ MCNT20c } & \multicolumn{3}{|c|}{ MCNT50 } & \multicolumn{3}{|c|}{ MCNT50c } \\
\hline & 25 & $\begin{array}{l}50 \\
\end{array}$ & 100 & 25 & $\begin{array}{l}50 \\
\end{array}$ & 100 & 25 & 50 & 100 & 25 & 50 & 100 & 25 & 50 & 100 & 25 & 50 & 100 & 25 & & \begin{tabular}{|c|}
100 \\
\end{tabular} & 25 & \begin{tabular}{|l|}
50 \\
\end{tabular} & \begin{tabular}{|l|l|}
100 \\
\end{tabular} \\
\hline EAhy & $24 \mathrm{~h}: 1.4$ & & 4h: 2.2 & $4 \mathrm{~h}: 1.8$ & & $4 \mathrm{~h}: 3.1$ & & & $4 \mathrm{~h}: 1.9$ & & $4 \mathrm{~h}: 3.4$ & $4 \mathrm{~h}: 4.0$ & 4h: 1.9 & 4h: 2.0 & $4 \mathrm{~h}: 2.3$ & $4 \mathrm{~h}: 1.4$ & & & \begin{tabular}{|l|l|}
$4 \mathrm{~h}: 1.8$ \\
\end{tabular} & $4 \mathrm{~h}: 1.4$ & 4 h: 3.0 & 4h: 1.3 & & \\
\hline L929 & $48 \mathrm{~h}: 1.8$ & & & 24h: 1.1 & & 4h: 1.2 & & & $48 \mathrm{~h}: 1.4$ & & & & $48 \mathrm{~h}: 2.2$ & $48 \mathrm{~h}: 1.3$ & S & & & & 48h: 1.5 & $5.48 \mathrm{~h}: 1.1$ & & $48 \mathrm{~h}: 1.6$ & $48 \mathrm{~h}: 1.2$ & \\
\hline V79 & $48 \mathrm{~h}: 1.3$ & & & \begin{tabular}{|l|l|}
$48 \mathrm{~h}: 5.1$ \\
\end{tabular} & $48 \mathrm{~h}: 1.1$ & & $48 \mathrm{~h}: 8.1$ & $48 \mathrm{~h}: 3$. & & 18h: 4. & $\begin{array}{l}48 \mathrm{~h}: 3.5 \\
\end{array}$ & $48 \mathrm{~h}: 2.3$ & 24h: 3.6 & $\begin{array}{l}48 \mathrm{~h}: 4.3 \\
\end{array}$ & $48 \mathrm{~h}: 3.6$ & $48 \mathrm{~h}: 2.6$ & $48 \mathrm{~h}: 4.3$ & $48 \mathrm{~h}: 1.8$ & 4 & (48: 2.8 & $48 \mathrm{~h}: 3$. & $48 \mathrm{~h}: 13.5$ & $48 \mathrm{~h}: 3.1$ & 4h: 2.3 \\
\hline
\end{tabular}

Dividing cells $>2.0$-fold

(b)

FIGURE 7: Detailed analysis of cellular reaction to CNTs according to Cell-IQ analysis software $(n=4)$. Necrotic cells (a) and dividing cells (b).

Limitations of the label-free methodologies used in this study were linked to the cells used. Measured impedance in the $x$ CELLigence system depends on cell-substrate adherence, cell shape and volume, and cell-cell-interactions. While MRC-5 fibroblasts and endothelial EAhy 926 cells reached the required CI of 1, DMBM-2 macrophages, apparently, showed too little adherence to the substrate and the CI was below 0.5. Mouse L929 fibroblasts also needed more than $24 \mathrm{~h}$ to reach the required CI value. Epithelial cells forming tight junctions appear to reach higher CI values than fibroblasts. Caco- 2 cells reached a CI of 5 [27], HUVEC of 6 [28], while diploid fetal fibroblasts reached 3.5 [29]. 
Decrease in viability to $<80 \%$

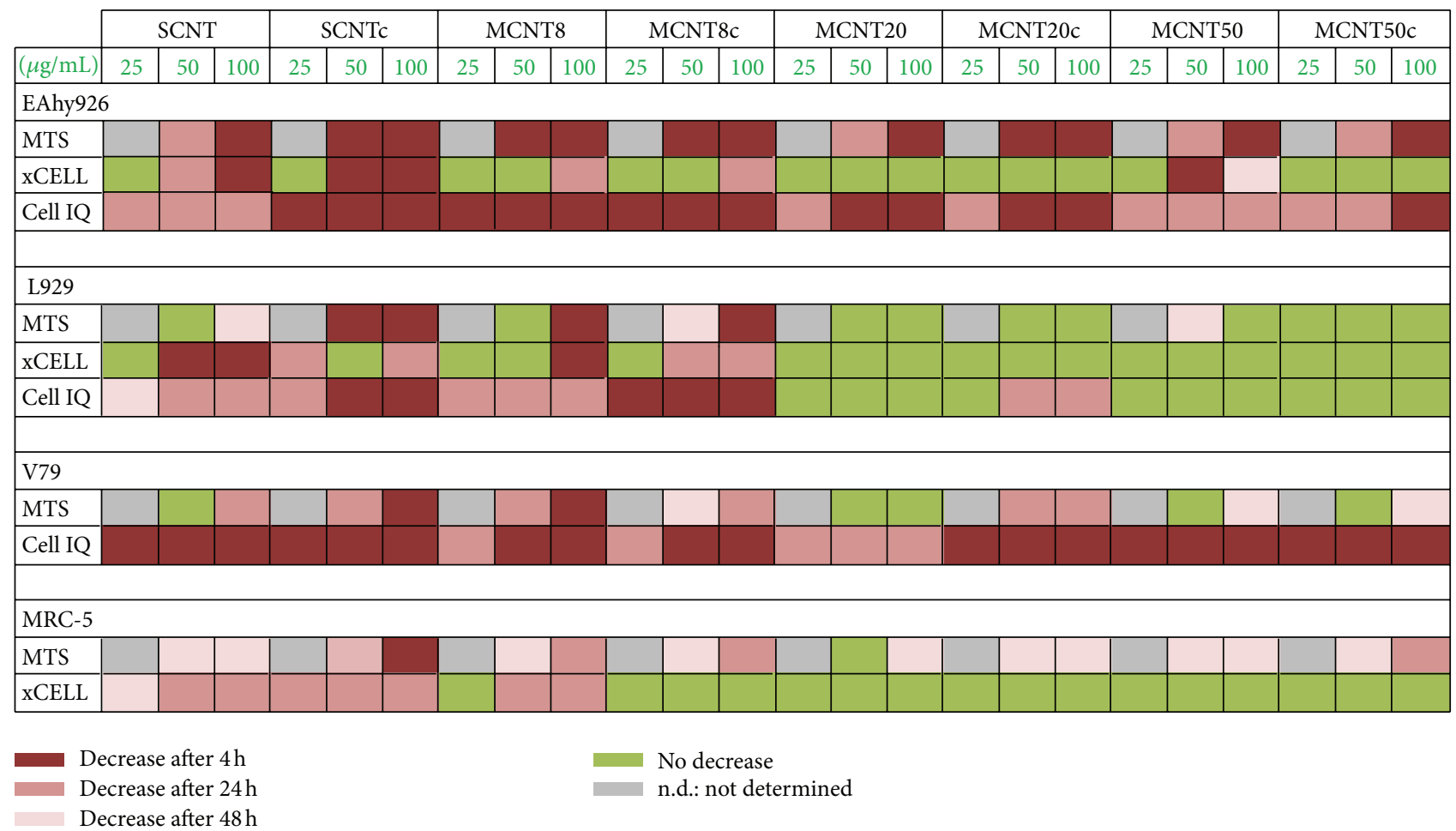

(a)

Recovery from cytotoxicity

\begin{tabular}{|c|c|c|c|c|c|c|c|c|c|c|c|c|c|c|c|c|c|c|c|c|c|c|c|c|}
\hline & \multicolumn{3}{|c|}{ SCNT } & \multicolumn{3}{|c|}{ SCNTc } & \multicolumn{3}{|c|}{ MCNT8 } & \multicolumn{3}{|c|}{ MCNT8c } & \multicolumn{3}{|c|}{ MCNT20 } & \multicolumn{3}{|c|}{ MCNT20c } & \multicolumn{3}{|c|}{ MCNT50 } & \multicolumn{3}{|c|}{ MCNT50c } \\
\hline$(\mu \mathrm{g} / \mathrm{mL})$ & 25 & 50 & 100 & 25 & 50 & 100 & 25 & 50 & 100 & 25 & 50 & 100 & 25 & 50 & 100 & 25 & 50 & 100 & 25 & 50 & 100 & 25 & 50 & 100 \\
\hline \multicolumn{25}{|c|}{ EAhy926 } \\
\hline \multicolumn{25}{|c|}{\begin{tabular}{|l|} 
MTS \\
\end{tabular}} \\
\hline \multicolumn{25}{|l|}{ Cell IQ } \\
\hline \multicolumn{25}{|l|}{ L929 } \\
\hline \multicolumn{25}{|l|}{ MTS } \\
\hline \multicolumn{25}{|l|}{ xCELL } \\
\hline \multicolumn{25}{|l|}{ Cell IQ } \\
\hline \multicolumn{25}{|l|}{ V79 } \\
\hline \multicolumn{25}{|l|}{ MTS } \\
\hline \multicolumn{25}{|l|}{ Cell IQ } \\
\hline \multicolumn{25}{|l|}{ MRC-5 } \\
\hline MTS & & & & & & & & & & & & & & & & & & & & & & & & \\
\hline
\end{tabular}

Increase at $24 \mathrm{~h}$

Increase at $48 \mathrm{~h}$

Not determined

(b)

Figure 8: Comparison of detection systems regarding decrease of viability to $<80 \%$ (a) and significant increases compared to viability at $4 \mathrm{~h}$ (recovery (b)). Higher sensitivity of cells and systems is indicated in deeper shades of red color, while exposures with lack of cytotoxicity are indicated in green. 
Ethanol showed a stronger effect in $x$ CELLigence than in the other two detection systems. Differences in cytotoxic effects can be explained by different degrees of confluence because confluent cells are more resistant to toxic damage than cells in the log phase $[30,31]$. Such differences are unlikely to play a role for the different sensitivity of EAhy 926 cells to ethanol in this study because cell densities in $x C E L$ Ligence were not lower than those used for MTS and CellIQ experiments (Table 2). The higher sensitivity, however, could be due to slower growth in the E-plates and could also explain the approximately three times higher sensitivity of CI measurements by $x$ CELLigence than viability in the WST-1 assay upon exposure to various cytostatic drugs [32]. After testing a panel of 21 conventional compounds, Atienzar et al. concluded that a CI decrease was not always associated with cytotoxicity effects and that confounding factors may affect the analysis [33]. $x$ CELLigence has also been evaluated for the toxicity testing of several types of NPs and similar sensitivity of impedance measurements and MTT were seen in RAW 264.7 macrophages exposed to $20 \mathrm{~nm} \mathrm{SiO}_{2}$ particles [34]. Testing of 11 inorganic nanomaterials by MTT assay and impedance measurements in 16HBE 140-cells identified $\mathrm{ZnO}, \mathrm{Mn}_{2} \mathrm{O}_{3}$, and $\mathrm{Ag}$ NPs as most cytotoxic in both systems [35]. Gadolinium NPs embedded in polysiloxane shell caused reduction in viability of MDA-MB 231 cells in $x$ CELLigence and MTT assays but decreases were visible much later in the $x$ CELLigence than in the MTT assay [36]. A decreased sensitivity of $x$ CELLigence to the cytotoxic action of CNTs compared to the other techniques was also observed in this study. Precipitation of CNTs on the electrode mimicking a higher coverage with cells or interference with the electric current used for impedance measurement could be reasons for the lower cytotoxic signal in this system.

Quality of analysis by Cell-IQ software was influenced by cell adhesion, cell size/shape, and cell deterioration. Loosely adherent or spindle-shaped cells posed problems and also the identification of apoptotic cells was not possible in this study. The formation of cell debris, seen after exposure of EAhy 926 cells to $20 \mathrm{~nm}$ AMI particles, decreased the quality of cell classification. Label-free automated microscopy with noncommercial systems has already been used in compound screening [37]. Cytotoxic effects of plant extracts to Ehrlich's lymphoma ascites (ELA) cancer cells have also been detected by automated microscopy and validated by manual analysis [38]. The possibility to assess cytotoxicity based on image analysis has been validated with lactate dehydrogenase release and life/dead staining [39]. This study shows that the system could be suitable for assessment of colored NPs, such as CNTs, because cell classification by Cell-IQ analysis software was not impaired. Inclusion of dividing and necrotic cells increased the sensitivity of cytotoxicity screening.

One of the major advantages of continuous detection is the possibility to identify transient decreases in viability. Such changes are important, since they indicate cellular adaptation mechanisms. While linear decreases in viability were reported, for instance, for DMSO [20] and for PAMAM dendrimers [40], recovery from NP damage was seen after exposure to gold NPs [41] and to $50 \mathrm{~nm}$ silica particles [42]. Testing of five types of NPs in a panel of cell lines, Díaz et al. identified recovery, usually after $48 \mathrm{~h}$ of exposure, to various magnetic NPs [43]. Adaptation on the cellular level appears also likely for CNTs since the relative decrease in cell numbers was more pronounced after 7 days than after 15 and 28 days of exposure [44]. Although not all time points were evaluated, cellular recovery in this study was mainly identified in xCELLigence and Cell-IQ exposures. It is not clear why, despite the absence of the analysis of additional time points, continuous monitoring techniques identified recovery while endpoint cytotoxicity screening by MTS did not.

\section{Conclusions}

Label-free techniques cannot be used as universally as MTS for cytotoxicity screening. If automated microscopy can be used, however, further analysis of the mode of toxic action (cell division, necrosis, etc.) is advantageous. Limitations were due to specific requirements for the cells used in both systems. On the other hand, precipitated NPs can interfere with impedance measurements and lead to underestimation of their cytotoxic potential.

\section{Conflict of Interests}

The authors declare that there is no conflict of interests.

\section{Acknowledgments}

This work was supported by the Austrian Science Fund Grant P 22576-B18. The technical help of Stefanie Mussger is gratefully acknowledged.

\section{References}

[1] L. Belyanskaya, P. Manser, P. Spohn, A. Bruinink, and P. Wick, "The reliability and limits of the MTT reduction assay for carbon nanotubes-cell interaction," Carbon, vol. 45, no. 13, pp. 2643-2648, 2007.

[2] M. Davoren, E. Herzog, A. Casey et al., "In vitro toxicity evaluation of single walled carbon nanotubes on human A549 lung cells," Toxicology in Vitro, vol. 21, no. 3, pp. 438-448, 2007.

[3] H. Isobe, T. Tanaka, R. Maeda et al., "Preparation, purification, characterization, and cytotoxicity assessment of watersoluble, transition-metal-free carbon nanotube aggregates," Angewandte Chemie, vol. 45, no. 40, pp. 6676-6680, 2006.

[4] N. A. Monteiro-Riviere, A. O. Inman, and L. W. Zhang, "Limitations and relative utility of screening assays to assess engineered nanoparticle toxicity in a human cell line," Toxicology and Applied Pharmacology, vol. 234, no. 2, pp. 222-235, 2009.

[5] J. Cveticanin, G. Joksic, A. Leskovac, S. Petrovic, A. V. Sobot, and O. Neskovic, "Using carbon nanotubes to induce micronuclei and double strand breaks of the DNA in human cells," Nanotechnology, vol. 21, no. 1, Article ID 015102, 2010.

[6] A. Casey, E. Herzog, M. Davoren, F. M. Lyng, H. J. Byrne, and G. Chambers, "Spectroscopic analysis confirms the interactions between single walled carbon nanotubes and various dyes commonly used to assess cytotoxicity," Carbon, vol. 45 , no. 7 , pp. 1425-1432, 2007. 
[7] X. Chen, C. Deng, S. Tang, and M. Zhang, "Mitochondriadependent apoptosis induced by nanoscale hydroxyapatite in human gastric cancer SGC-7901 cells," Biological \& Pharmaceutical Bulletin, vol. 30, no. 1, pp. 128-132, 2007.

[8] C. A. Sabatini, R. V. Pereira, and M. H. Gehlen, "Fluorescence modulation of acridine and coumarin dyes by silver nanoparticles," Journal of Fluorescence, vol. 17, no. 4, pp. 377-382, 2007.

[9] R. H. Hurt, M. Monthioux, and A. Kane, "Toxicology of carbon nanomaterials: status, trends, and perspectives on the special issue," Carbon, vol. 44, no. 6, pp. 1028-1033, 2006.

[10] M. A. Hasnat, M. M. Uddin, A. J. F. Samed, S. S. Alam, and S. Hossain, "Adsorption and photocatalytic decolorization of a synthetic dye erythrosine on anatase $\mathrm{TiO}_{2}$ and $\mathrm{ZnO}$ surfaces," Journal of Hazardous Materials, vol. 147, no. 1-2, pp. 471-477, 2007.

[11] S. H. Doak, S. M. Griffiths, B. Manshian et al., "Confounding experimental considerations in nanogenotoxicology," Mutagenesis, vol. 24, no. 4, pp. 285-293, 2009.

[12] R. C. Murdock, L. Braydich-Stolle, A. M. Schrand, J. J. Schlager, and S. M. Hussain, "Characterization of nanomaterial dispersion in solution prior to in vitro exposure using dynamic light scattering technique," Toxicological Sciences, vol. 101, no. 2, pp. 239-253, 2008.

[13] M. Gonzales, L. M. Mitsumori, J. V. Kushleika, M. E. Rosenfeld, and K. M. Krishnan, "Cytotoxicity of iron oxide nanoparticles made from the thermal decomposition of organometallics and aqueous phase transfer with Pluronic F127," Contrast Media and Molecular Imaging, vol. 5, no. 5, pp. 286-293, 2010.

[14] J. M. Wörle-Knirsch, K. Pulskamp, and H. F. Krug, "Oops they did it again! Carbon nanotubes hoax scientists in viability assays," Nano Letters, vol. 6, no. 6, pp. 1261-1268, 2006.

[15] E. Fröhlich, C. Meindl, A. Höfler, G. Leitinger, and E. Roblegg, "Combination of small size and carboxyl functionalisation causes cytotoxicity of short carbon nanotubes," Nanotoxicology, vol. 7, pp. 1211-1224, 2013.

[16] B. Xi, N. Yu, X. Wang, X. Xu, and Y. A. Abassi, "The application of cell-based label-free technology in drug discovery," Biotechnology Journal, vol. 3, no. 4, pp. 484-495, 2008.

[17] F. Hajighasemi and N. Kakadezfuli, "Sensitivity of monocytic cell lines to verapamil in vitro," Research Journal of Biological Sciences, vol. 7, no. 5, pp. 209-214, 2012.

[18] S. Liu, L. Xu, T. Zhang, G. Ren, and Z. Yang, "Oxidative stress and apoptosis induced by nanosized titanium dioxide in PC12 cells," Toxicology, vol. 267, no. 1-3, pp. 172-177, 2010.

[19] G. M. Williams and M. J. Iatropoulos, "Alteration of liver cell function and proliferation: differentiation between adaptation and toxicity," Toxicologic Pathology, vol. 30, no. 1, pp. 41-53, 2002.

[20] S. G. Mukherjee, N. O’Claonadh, A. Casey, and G. Chambers, "Comparative in vitro cytotoxicity study of silver nanoparticle on two mammalian cell lines," Toxicology in Vitro, vol. 26, no. 2, pp. 238-251, 2012.

[21] J. M. Seiffert, M.-O. Baradez, V. Nischwitz, T. Lekishvili, H. Goenaga-Infante, and D. Marshall, "Dynamic monitoring of metal oxide nanoparticle toxicity by label free impedance sensing," Chemical Research in Toxicology, vol. 25, no. 1, pp. 140152, 2012.

[22] J. A. Sergent, V. Paget, and S. Chevillard, "Toxicity and genotoxicity of nano- $\mathrm{SiO}_{2}$ on human epithelial intestinal HT-29 cell line," Annals of Occupational Hygiene, vol. 56, no. 5, pp. 622-630, 2012.
[23] P. D. Caie, R. E. Walls, A. Ingleston-Orme et al., "High-content phenotypic profiling of drug response signatures across distinct cancer cells," Molecular Cancer Therapeutics, vol. 9, no. 6, pp. 1913-1926, 2010.

[24] G. F. Ma, Q. Miao, X. Q. Zeng et al., "Transforming growth factor-betal and -beta 2 in gastric precancer and cancer and roles in tumor-cell interactions with peripheral blood mononuclear cells in vitro," PloS ONE, vol. 8, no. 1, Article ID e54249, 2013.

[25] S. Spulber, K. Edoff, L. Hong et al., "Molecular hydrogen reduces LPS-induced neuroinflammation and promotes recovery from sickness behaviour in mice," PloS ONE, vol. 7, no. 7, Article ID e42078, 2012.

[26] V. Talman, R. K. Tuominen, G. B. af Gennäs, J. Yli-Kauhaluoma, and E. Ekokoski, "Cl domain-targeted isophthalate derivatives induce cell elongation and cell cycle arrest in HeLa cells," PLoS ONE, vol. 6, no. 5, Article ID e20053, 2011.

[27] C. Danussi, A. Petrucco, B. Wassermann et al., "EMILIN1- $\alpha 4 / \alpha 9$ integrin interaction inhibits dermal fibroblast and keratinocyte proliferation," Journal of Cell Biology, vol. 195, no. 1, pp. 131-145, 2011.

[28] S. Rahim and A. Üren, "A real-time electrical impedance based technique to measure invasion of endothelial cell monolayer by cancer cells," Journal of Visualized Experiments, no. 50, Article ID e2792, 2011.

[29] G. X. Mao, L. D. Zheng, Y. B. Cao et al., "Antiaging effect of pine pollen in human diploid fibroblasts and in a mouse model induced by D-galactose," Oxidative Medicine and Cellular Longevity, vol. 2012, Article ID 750963, 10 pages, 2012.

[30] B. C. Heng, X. Zhao, S. Xiong, K. W. Ng, F. Y.-C. Boey, and J. S.-C. Loo, "Cytotoxicity of zinc oxide ( $\mathrm{ZnO}$ ) nanoparticles is influenced by cell density and culture format," Archives of Toxicology, vol. 85, no. 6, pp. 695-704, 2011.

[31] R. L. Persinger, W. M. Blay, N. H. Heintz, D. R. Hemenway, and Y. M. W. Janssen-Heininger, "Nitrogen dioxide induces death in lung epithelial cells in a density-dependent manner," American Journal of Respiratory Cell and Molecular Biology, vol. 24, no. 5, pp. 583-590, 2001.

[32] N. Ke, X. Wang, X. Xu, and Y. A. Abassi, "The xCELLigence system for real-time and label-free monitoring of cell viability," Methods in Molecular Biology, vol. 740, pp. 33-43, 2011.

[33] F. A. Atienzar, K. Tilmant, H. H. Gerets et al., "The use of real-time cell analyzer technology in drug discovery: defining optimal cell culture conditions and assay reproducibility with different adherent cellular models," Journal of Biomolecular Screening, vol. 16, no. 6, pp. 575-587, 2011.

[34] H. Yang, Q. Wu, M. Tang et al., "In vitro study of silica nanoparticle-lnduced cytotoxicity based on real-time cell electronic sensing system," Journal of Nanoscience and Nanotechnology, vol. 10, no. 1, pp. 561-568, 2010.

[35] L. Otero-Gonzalez, R. Sierra-Alvarez, S. Boitano, and J. A. Field, "Application and validation of an impedance-based real time cell analyzer to measure the toxicity of nanoparticles impacting human bronchial epithelial cells," Environmental Science \& Technology, vol. 46, no. 18, pp. 10271-10278, 2012.

[36] H. Benachour, T. Bastogne, M. Toussaint et al., "Real-time monitoring of photocytotoxicity in nanoparticles-based photodynamic therapy: a model-based approach," PloS ONE, vol. 7, no. 11, Article ID e48617, 2012.

[37] N. H. Pipalia, A. Huang, H. Ralph, M. Rujoi, and F. R. Maxfield, "Automated microscopy screening for compounds that partially revert cholesterol accumulation in Niemann-Pick C cells," Journal of Lipid Research, vol. 47, no. 2, pp. 284-301, 2006. 
[38] B. Gopinath and N. Shanth, "Automated segmentation of ELA cancer cells in microscopic images for evaluating the cytotoxic effect of selected medicinal plants," Journal of Medical and Biological Engineering, vol. 32, no. 4, pp. 279-286, 2012.

[39] M. Athelogou, M. Eblenkamp, G. Schmidt et al., "Image analysis for calculation of the toxicity degree of cells," in Phase Contrast Microscopy Images, Springer, Berlin, Germany, 2011.

[40] P. C. Naha, M. Davoren, F. M. Lyng, and H. J. Byrne, "Reactive oxygen species (ROS) induced cytokine production and cytotoxicity of PAMAM dendrimers in J774A.1 cells," Toxicology and Applied Pharmacology, vol. 246, no. 1-2, pp. 91-99, 2010.

[41] J. Nellore, P. C. Pauline, and K. Amarnath, "Biogenic synthesis by Sphearanthus amaranthoids; towards the efficient production of the biocompatible gold nanoparticles," Digest Journal of Nanomaterials and Biostructures, vol. 7, no. 1, pp. 123-133, 2012.

[42] M. P. Casado, A. Macken, and H. J. Byrne, "Ecotoxicological assessment of silica and polystyrene nanoparticles assessed by a multitrophic test battery," Environment International, vol. 51, pp. 97-105, 2013.

[43] B. Díaz, C. Sánchez-Espinel, M. Arruebo et al., "Assessing methods for blood cell cytotoxic responses to inorganic nanoparticles and nanoparticle aggregates," Small, vol. 4, no. 11, pp. 20252034, 2008.

[44] M. Mrakovcic, M. Absenger, R. Riedl, E. Roblegg, and E. Fröhlich, "Assessment of long-term effects of nanoparticles in a MiCROCARRIER cell culture system," PLoS ONE, vol. 8, no. 2, Article ID e56791, 2013. 

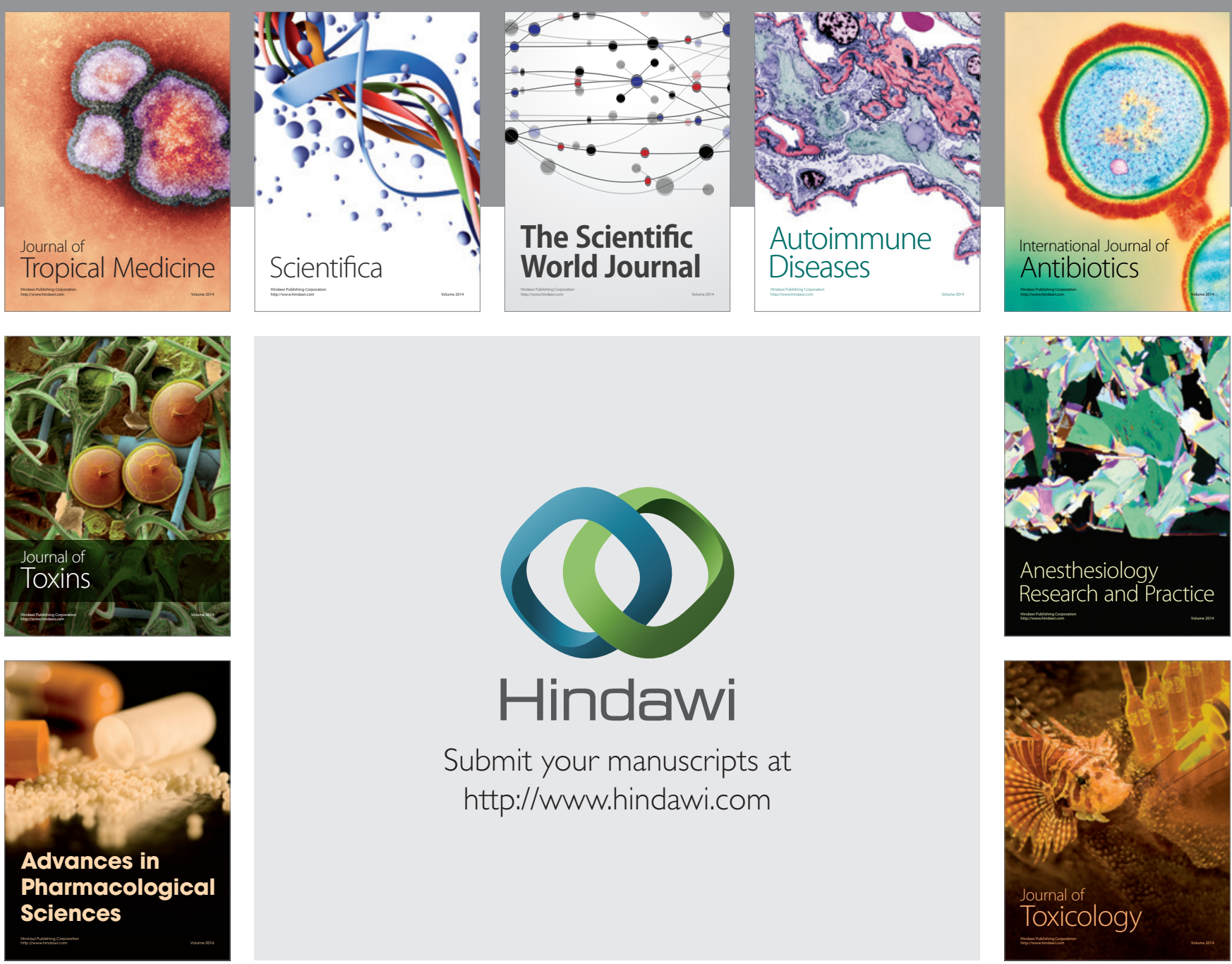

\section{Hindawi}

Submit your manuscripts at

http://www.hindawi.com
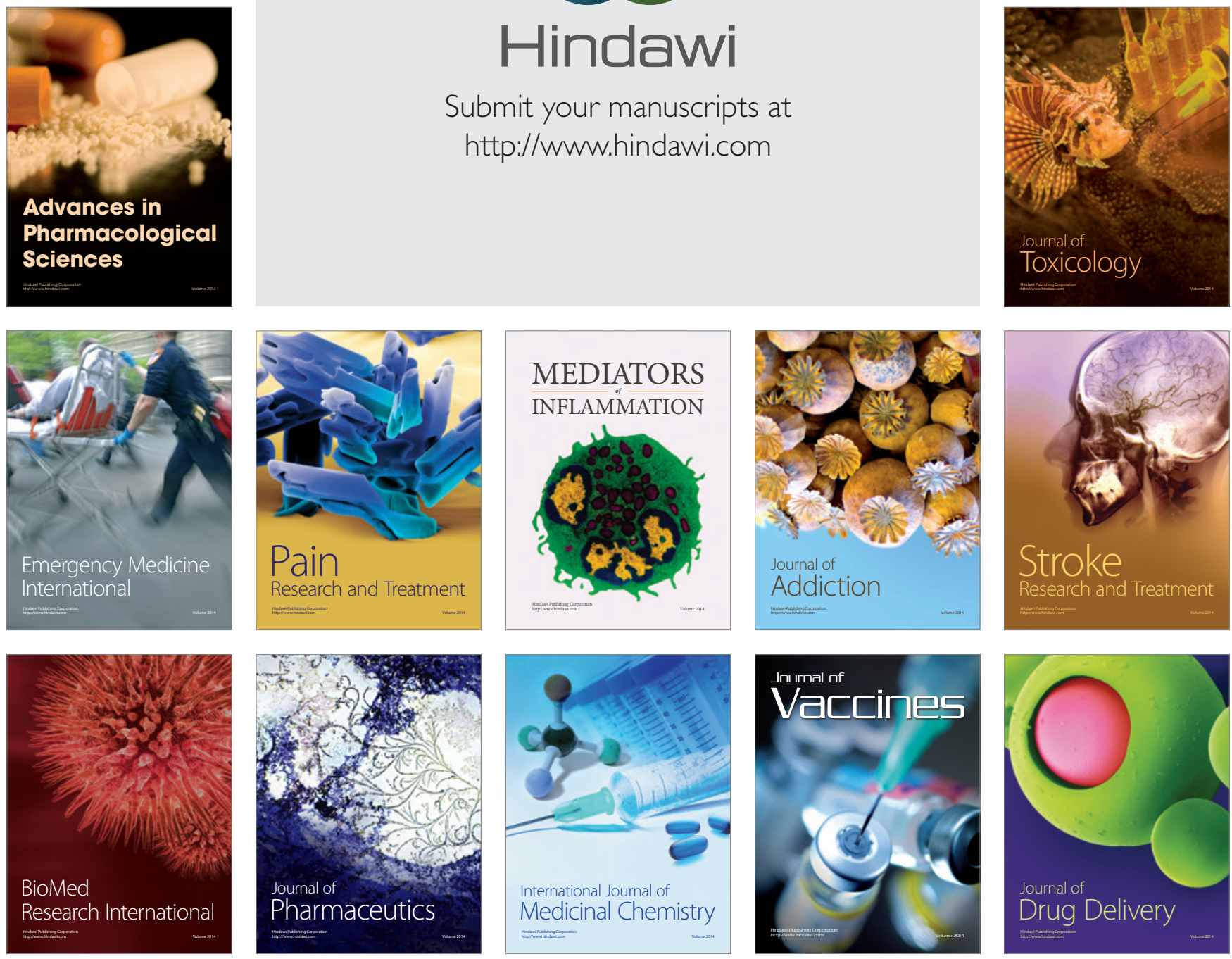